\title{
PENGARUH MINAT DAN MOTIVASI BELAJAR TERHADAP PRESTASI BELAJAR FISIKA PADA SISWA KELAS XI IPA SMA NEGERI 1 GALING KABUPATEN SAMBAS
}

\author{
Ira Nofita Sari ${ }^{1}$, Dwi Fajar Saputri ${ }^{2}$, Sasmita $^{3}$ \\ ${ }^{1,2,3}$ Prodi Pendidikan Fisika IKIP PGRI Pontianak \\ e-mail: ${ }^{1}$ iranofitasari87@gmail.com; ${ }^{2}$ dwifajar24@gmail.com: ${ }^{3}$ sasmita@yahoo.com
}

\begin{abstract}
Abstrak
Penelitian ini bertujuan untuk mengetahui pengaruh minat dan motivasi belajar terhadap prestasi belajar fisika pada siswa kelas XI IPA SMA Negeri 1 Galing kabupaten Sambas. Adapun variabel dalam penelitian ini yaitu minat dan motivasi belajar sebagai variabel bebas terhadap prestasi belajar fisika pada siswa kelas XI IPA SMA Negeri 1 Galing Kabupaten Sambas sebagai varibel terikat. Metode yang digunakan dalam penelitian ini adalah metode deskriptif dan bentuk penelitian hubungan (interrelationship studies), studi sebab akibat (causal-comparative studies). Sampel penelelitian ini adalah seluruh siswa kelas XI IPA yang terdiri dari 29 siswa. Teknik pengumpul data berupa teknik komunikasi tidak langsung, teknik studi dokumenter, dan teknik observasi langsung dengan alat pengumpul data yang digunakan adalah angket, buku nilai dan pedoman observasi.Berdasarkan hasil analisis data diperoleh nilai $F_{\text {hitung }}$ sebesar 11,00 > nilai $F_{\text {tabel }}$ sebesar 3,37, maka $H_{o}$ ditolak dan $H_{a}$ diterima. Hal ini berarti terdapat pengaruh minat dan motivasi belajar terhadap prestasi belajar fisika pada siswa kelas XI IPA SMA Negeri 1 Galing Kabupaten Sambas dengan nilai koefisien determinasi sebesar 0,46, yang menunjukkan bahwa $46 \%$ prestasi belajar fisika siswa dipengaruhi oleh minat dan motivasi belajar sedangkan sisanya sebesar 54\% dipengaruhi oleh variabel lain yang tidak termasuk dalam penelitian ini.
\end{abstract}

Kata Kunci: minat; motivasi; prestasi belajar fisika

\section{PENDAHULUAN}

Pendidikan pada hakekatnya adalah
usaha sadar untuk mengembangkan kepribadian dan kemampuan di dalam dan di luar sekolah (Undang-undang Republik Indonesia Nomor 20 Tahun 2003 tentang Sistem Pendidikan Nasional). Pendidikan berperan penting dalam meningkatkan kualitas sumber daya manusia yang mendukung kemajuan pembangunan, salah satunya adalah pendidikan MIPA. Pendidikan MIPA merupakan cabang ilmu pendidikan yang perlu mendapatkan perhatian, karena menjadi dasar bagi perkembangan ilmu pengetahuan dan teknologi (IPTEK). Mata pelajaran yang termasuk dalam cabang ilmu pendidikan MIPA adalah mata pelajaran fisika.

Menurut Kanginan (2004), fisika adalah ilmu fundamental yang menjadi tulang punggung bagi perkembangan ilmu pengetahuan dan teknologi. Fisika adalah bidang studi yang diberikan di Sekolah
Menengah Atas (SMA) dengan tujuan untuk memberikan seperangkat pengetahuan, bentukbentuk keterampilan dan penanaman sikap dan nilai dalam konteks disiplin ilmu fisika (Depdiknas, 2007). Melihat tujuan tersebut, pelajaran fisika di SMA dikembangkan dalam kerangka memberikan pengalaman langsung kepada siswa dalam menjelajahi dan memahami alam di sekitarnya secara ilmiah dan mempersiapkan siswa yang melek sains dan teknologi untuk memahami dirinya dan lingkungan sekitarnya, melalui pengembangan keterampilan proses, keterampilan berfikir, penguasaan konsep sains dan kegiatan teknologi. Pendidikan fisika menekankan pada pemberian pengalaman secara langsung kepada siswa tentang konsep, prinsip, dan proses penemuan dalam materi-materi fisika. Tujuan pendidikan fisika dapat dicapai, apabila siswa bisa mencapai kompetensi pembelajaran.

Kompetensi pembelajaran dalam suatu proses belajar mengajar pada suatu satuan 
pendidikan terutama di Sekolah Menengah Atas dinyatakan tercapai bila terjadi peningkatan prestasi belajar siswa dalam pelajaran yang diikutinya. Prestasi belajar adalah hasil pengukuran dari penilaian usaha belajar yang dinyatakan dalam bentuk angka, simbol, huruf maupun kalimat yang menceritakan hasil yang sudah dicapai oleh setiap siswa pada periode tertentu (Hamdani, 2011). Prestasi belajar siswa dapat diketahui setelah diadakan evalusi pembelajaran. Hasil dari evaluasi dapat memperlihatkan tinggi rendahnya prestasi belajar siswa. Tinggi rendahnya prestasi belajar siswa dibuktikan dengan hasil belajar siswa yang memenuhi Kriteria Ketuntasan Minimum (KKM). Mencapai nilai Kriteria Ketuntasan Minimum (KKM) bukanlah suatu hal yang mudah. Hal itu dikarenakan keberhasilan belajar dalam mencapai kompetensi pelajaran sangat dipengaruhi oleh banyak faktor.

Menurut Ahmadi (2005) faktor-faktor yang mempengaruhi prestasi belajar dapat digolongkan menjadi dua bagian, yaitu faktor dari dalam (intern) dan faktor dari luar (ekstern). Faktor intern adalah faktor yang berasal dari siswa. Berikut yang termasuk dalam faktor intern antara lain kecerdasan (intelegensi), faktor jasmaniah atau faktor fisiologis, sikap, minat, bakat dan kecerdasan. Selanjutnya, yang termasuk faktor ekstern terdiri atas dua macam, yaitu faktor lingkungan sosial dan lingkungan nonsosial. Selain itu, Slameto (2013) menyatakan bahwa faktor ekstern yang dapat mempengaruhi belajar adalah keadaan keluarga, keadaan sekolah, dan lingkungan masyarakat. Faktor intern dan ekstern sangat berpengaruh terhadap prestasi belajar siswa. Salah satu faktor yang berpengaruh besar adalah faktor minat dan motivasi. Menurut Dalyono (dalam Djamarah, 2013) minat belajar yang besar cenderung menghasilkan prestasi yang tinggi, sebaliknya minat belajar yang kurang akan menghasilkan prestasi belajar yang rendah. Begitu pula menurut Djamarah (2011) motivasi dalam belajar dapat menentukan baik tidaknya dalam mencapai tujuan. Semakin besar motivasi maka semakin besar kesuksesan dalam belajar, sehingga berdampak pada meningkatnya prestasi belajar siswa. Oleh karena itu, dapat kita ketahui bahwa faktor minat dan motivasi menjadi salah satu faktor yang menentukan prestasi belajar yang dicapai oleh siswa.

Kenyataannya, berdasarkan wawancara terhadap guru mata pelajaran fisika yang dilakukan oleh peneliti di SMA Negeri 1 Galing, didapatkan hasil mengenai prestasi belajar fisika siswa yang masih rendah dan belum mencapai KKM yaitu 75 dengan persentase ketuntasan sebesar 56,55\%.

Begitu pula hasil observasi yang dilakukan peneliti terhadap siswa kelas XI IPA pada saat mengikuti proses belajar mengajar di kelas didapatkan hasil bahwa pada saat mengikuti pelajaran terdapat siswa yang kurang memperhatikan guru, baik pada saat guru menjelaskan materi pelajaran ataupun pada saat guru memberikan latihan atau contoh soal. Selain itu, kurang aktifnya siswa di kelas pada saat proses belajar mengajar berlangsung yang ditunjukkan dengan kurangnya siswa bertanya. Selain itu, peneliti juga melakukan tanya jawab dengan guru mata pelajaran fisika, dan diketahui bahwa saat diberikan tugas, masih terdapat siswa yang tidak mengerjakan tugas.

Menurut Slameto (2013), siswa yang kurang memperhatikan pelajaran mengindikasikan bahwa siswa memiliki minat belajar yang rendah karena diketahui bahwa minat belajar adalah suatu ketertarikan atau kecenderungan yang tetap untuk memperhatikan dan mengenang beberapa kegiatan, dalam hal ini berupa kegiatan belajar. Jika siswa tertarik pada suatu mata pelajaran, siswa akan lebih memperhatikan pelajaran yang telah membuatnya tertarik. Begitu pula bagi siswa yang kurang aktif dan tidak mengerjakan tugas mengindikasikan bahwa siswa tersebut kurang memiliki motivasi belajar, karena motivasi adalah segala sesuatu yang mendorong seseorang untuk melakukan sesuatu (Purwanto, 2013). Siswa yang memiliki motivasi yang kurang menyebabkan siswa memiliki dorongan yang kurang untuk belajar.

Rendahnya prestasi belajar fisika yang didapat oleh siswa disebabkan banyak faktor. Bersesuaian dengan hasil observasi yang telah dijabarkan sebelumnya, bahwa siswa kelas XI IPA diindikasikan memiliki minat dan motivasi belajar yang masih kurang. Minat dan motivasi belajar siswa yang masih kurang akan 
berakibat pada prestasi belajar yang didapat oleh siswa.

Sehubungan dengan uraian di atas, maka peneliti ingin mengetahui lebih lanjut tentang apakah minat dan motivasi belajar mempengaruhi prestasi belajar fisika yang didapat siswa kelas XI IPA SMA Negeri 1 Galing Kabupaten Sambas. Oleh karena itu, peneliti mengangkat pengaruh minat dan motivasi belajar siswa terhadap prestasi belajar fisika pada siswa kelas XI IPA SMA Negeri 1 Galing Kabupaten Sambas sebagai judul penelitian ini.

\section{METODE PENELITIAN}

Metode yang digunakan dalam penelitian ini adalah metode deskriptif. Metode ini digunakan untuk menggambarkan pengaruh minat dan motivasi belajar siswa terhadap prestasi belajar fisika pada siswa kelas XI IPA SMA Negeri 1 Galing Kabupaten Sambas berdasarkan fakta-fakta atau data-data yang diperoleh dari hasil penelitian.

Penelitian ini dilakukan di SMA Negeri 1 Galing Kabupaten Sambas, dengan jumlah populasi adalah keseluruhan siswa kelas XI IPA SMA Negeri 1 Galing.

Teknik pengumpulan data yang digunakan dalam penelitian ini adalah komunikasi tidak langsung yang berupa angket yang digunakan untuk mengukur minat dan motivasi belajar fisika siswa, dengan berupa angket tertutup berbentuk pernyataan dengan pilihan jawaban. Skala pengukuran yang digunakan dalam angket adalah skala likert. Selain itu, dalam penelitian ini juga menggunakan teknik studi dokumenter yaitu berupa buku nilai ulangan akhir semester genap mata pelajaran fisika kelas XI IPA SMA Negeri 1 Galing tahun ajaran 2013/2014,yang digunakan untuk menentukan tingkat prestasi siswa, serta teknik observasi langsung dengan menggunakan panduan observasi untuk mengetahui minat dan motivasi belajar siswa pada saat mengikuti pelajaran di kelas.

Analisis data yang digunakan untuk mendiskripsikan data minat belajar, motivasi belajar dan prestasi belajar fisika dilakukan menggunakan statistik deskriptif yaitu meliputi perhitungan persentase terhadap data minat dan motivasi belajar sesuai dengan persamaan:

Keterangan:

$$
X \%=\frac{n}{N} X 100 \%
$$

$X \quad=$ Persentase

$n \quad=$ Jumlah skor aktual

$N \quad=$ Jumlah skor maksimal

Ali (Ali, 2011)

Kategori minat dan motivasi seseai dengan kriteria interpretasi sesuai dengan Tabel 1.

Tabel 1. Kriteria Interpretasi Persentase Skor Angket dan Observasi

\begin{tabular}{cl}
\hline Persentase Skor & Kriteria \\
\hline \hline $0 \%-33 \%$ & Rendah \\
$34 \%-67 \%$ & Sedang \\
$68 \%-100 \%$ & Tinggi \\
\hline
\end{tabular}

Purwanto (2011: 187)

Adapun pengujian hipotesis dalam penelitian ini menggunakan uji regresi linier berganda seseuai dengan persamaan :

Keterangan:

$$
F_{\mathrm{h}}=\frac{\mathrm{R}^{2}(\mathrm{n}-\mathrm{K}-1)}{\mathrm{k}\left(1-\mathrm{R}^{2}\right)}
$$

$$
\begin{array}{ll}
K & =\text { Koefisien Korelasi } \\
k & =\text { Jumlah variabel indipeden } \\
n & =\text { Jumlah anggota sampel }
\end{array}
$$

(Sugiyono, 2011)

\section{HASIL PENELITIAN DAN PEMBAHASAN}

Penelitian yang dilakukan merupakan penelitian diskriptif yang dilakukan di SMA Negeri 1 Galing pada tanggal yang dilakukan terhadap 29 orang siswa sebagai sampel penelitian yang diambil dari keseluruhan anggota populasi siswa kelas XI IPA SMA Negeri 1 Galing. Data yang dianalisis adalah minat dan motivasi belajar fisika siswa. Data nilai prestasi belajar fisika siswa didapat dari guru mata pelajaran fisika tempat penelitian dilakukan. Sedangkan data minat belajar fisika 
JEMS (Jurnal Edukasi Matematika dan Sains)

Tersedia online di: http://e-journal.ikippgrimadiun.ac.id/index.php/JEMS

Volume 4, Nomor 2, September 2016, hal 108-114

diperoleh melalui angket dan hasil observasi

langsung peneliti ke dalam kelas.

Tabel 2. Minat Belajar Fisika berdasarkan Angket

\begin{tabular}{ccc}
\hline $\begin{array}{c}\text { Kategori Minat } \\
\text { Belajar }\end{array}$ & $\begin{array}{c}\text { Jumlah } \\
\text { Siswa }\end{array}$ & $\%$ \\
\hline Tinggi & 29 & 100,00 \\
\hline Sedang & 0 & 00,00 \\
\hline Rendah & 0 & 00,00 \\
\hline
\end{tabular}

Berdasarkan Tabel 2 terlihat bahwa minat belajar fisika tergolong tinggi dengan persentase sebesar $100 \%$, tidak terdapat siswa yang termasuk dalam kategori minat belajar sedang dan rendah.

Tabel 3. Minat Belajar Fisika berdasarkan Hasil Observasi

\begin{tabular}{lcc}
\hline \multicolumn{1}{c}{ Indikator Minat Belajar } & $\%$ & Kategori \\
\hline Keingintahuan & 70,31 & Tinggi \\
\hline Kebutuhan & 92,19 & Tinggi \\
\hline Perhatian & 71,09 & Tinggi \\
\hline Rata-rata & 76,79 & Tinggi
\end{tabular}

Berdasarkan Tabel 3 dapat diketahui bahwa minat belajar fisika berdasarkan hasil observasi memiliki rata-rata sebesar $76,79 \%$. Minat belajar memiliki 3 indikator yaitu keingintahuan, kebutuhan, dan perhatian.

Indikator minat belajar siswa tentang keingintahuan dalam belajar fisika sebesar $70,31 \%$, artinya minat belajar siswa berkenaan keingintahuan dalam belajar tergolong tinggi.

Indikator minat belajar siswa tentang kebutuhan dalam belajar sebesar 92,19\%, artinya minat belajar siswa berkenaan kebutuhan dalam belajar tergolong tinggi.

Indikator minat belajar siswa tentang perhatian dalam belajar sebesar 71,09\%, artinya minat belajar siswa berkenaan perhatian dalam belajar tergolong tinggi.

Analisis data menunjukkan bahwa secara umum minat belajar fisika siswa kelas XI IPA SMA Negeri 1 Galing tergolong tinggi. Minat belajar fisika adalah ketertarikan dan kecenderungan yang tetap untuk memperhatikan dan terlibat dalam aktivitas belajar karena menyadari penting atau bernilainya hal yang dipelajari khususnya dalam mempelajari fisika. Minat belajar merupakan salah satu faktor psikologis yang mempengaruhi belajar siswa dan juga merupakan salah satu alat motivasi yang utama
Adapun minat belajar fisika berdasarkan hasil observasi minat belajar untuk tiap indikator dapat dilihat dalam Tabel 3.

yang dapat membangkitkan gairah belajar siswa. Menurut Dalyono (dalam Djamarah, 2011) minat belajar yang besar cenderung menghasilkan prestasi yang tinggi, sebaliknya minat belajar yang kurang akan menghasilkan prestasi yang rendah, sehingga dapat dikatakan bahwa untuk bisa mendapatkan prestasi belajar yang tinggi, seorang siswa harus memiliki minat belajar yang besar pula. Oleh karena itu, minat belajar siswa harus dibangkitkan agar siswa lebih tertarik terhadap pelajaran yang diberikan guru.

Salah satu cara yang dapat dilakukan adalah dengan membangkitkan rasa ingin tahu siswa terhadap materi pelajaran, membangkitkan rasa kebutuhan siswa terhadap pelajaran, serta meningkatkan perhatian siswa dalam menerima pelajaran. Hal ini sesuai dengan pendapat Reber (dalam Syah, 2011) yang menyatakan bahwa minat tergantung pada faktor-faktor internal lainnya seperti pemusatan perhatian, keingintahuan, dan kebutuhan. Oleh karena itu, untuk meningkatkan minat belajar siswa, guru harus lebih memperhatikan rasa ingin tahu siswa terhadap materi pelajaran, kebutuhan siswa terhadap pelajaran, serta perhatian siswa dalam menerima pelajaran. 
JEMS (Jurnal Edukasi Matematika dan Sains)

Tersedia online di: http://e-journal.ikippgrimadiun.ac.id/index.php/JEMS

Volume 4, Nomor 2, September 2016, hal 108-114

Tabel 4. Motivasi Belajar Fisika berdasarkan Angket

\begin{tabular}{ccc}
\hline Kategori Motivasi Belajar & $\begin{array}{c}\text { Jumlah } \\
\text { Siswa }\end{array}$ & $\%$ \\
\hline Tinggi & 28 & 96,55 \\
\hline Sedang & 1 & 3,45 \\
\hline Rendah & 0 & 00,00 \\
\hline
\end{tabular}

Data motivasi belajar fisika diperoleh melalui penyebaran angket dan observasi langsung terhadap siswa. Hasil motivasi belajar disajikan dalam Tabel 4 dan Tabel 5.

Berdasarkan Tabel 4 terlihat bahwa motivasi belajar pada mata pelajaran fisika siswa kelas XI IPA SMA Negeri 1 Galing jumlah siswa yang termasuk dalam motivasi belajar fisika yang terkategori tinggi berjumlah 28 orang siswa dengan persentase sebesar 96,55\%. Sedangkan siswa yang termasuk

dalam motivasi belajar fisika siswa yang terkategori sedang berjumlah 1 orang siswa dengan persentase sebesar $3,45 \%$.

Adapun motivasi belajar fisika berdasarkan hasil observasi pada Tabel 5 menunjukan bahwa motivasi belajar pada mata pelajaran fisika siswa kelas XI IPA SMA Negeri 1 Galing rata-rata tergolong tinggi dengan persentase sebesar $73,44 \%$.

Tabel 5. Motivasi Belajar Fisika berdasarkan Observasi

\begin{tabular}{lcc}
\hline \multicolumn{1}{c}{ Indikator Motivasi Belajar } & $\%$ & Kategori \\
\hline Kebutuhan fisiologis & 81,25 & Tinggi \\
\hline Kebutuhan rasa aman & 92,19 & Tinggi \\
\hline Kebutuhan rasa cinta & 70,31 & Tinggi \\
\hline Kebutuhan akan penghargaan & 68,75 & Tinggi \\
\hline Kebutuhan aktualisasi diri & 57,81 & Sedang \\
\hline Kebutuhan mengerti dan mengetahui & 71,88 & Tinggi \\
\hline Rata-rata & 73,44 & Tinggi \\
\hline belajar siswa secara rinci & Indikator motivasi belajar siswa
\end{tabular}

dapat dilihat berdasarkan indikator-indikator motivasi belajar antara lain kebutuhan fisiologis, kebutuhan rasa aman, kebutuhan rasa cinta, kebutuhan akan penghargaan, kebutuhan aktualisasi diri, kebutuhan mengerti dan mengetahui.

Indikator motivasi belajar siswa tentang kebutuhan fisiologis dalam belajar sebesar $81,25 \%$, artinya motivasi belajar siswa berkenaan kebutuhan fisiologis dalam belajar tergolong tinggi.

Indikator motivasi belajar siswa tentang kebutuhan rasa aman dalam belajar sebesar $92,19 \%$, artinya motivasi belajar siswa berkenaan kebutuhan rasa aman dalam belajar tergolong tinggi.

Indikator motivasi belajar siswa tentang kebutuhan rasa cinta dalam belajar sebesar $70,31 \%$, artinya motivasi belajar siswa berkenaan kebutuhan rasa cinta dalam belajar tergolong tinggi.

Indikator motivasi belajar siswa tentang kebutuhan akan penghargaan dalam belajar sebesar 68,75\%, artinya motivasi belajar siswa berkenaan kebutuhan akan penghargaan dalam belajar tergolong tinggi. tentang kebutuhan aktualisasi diri dalam belajar sebesar $57,81 \%$, artinya motivasi belajar siswa berkenaan kebutuhan aktualisasi diri dalam belajar tergolong sedang.

Analisis data menunjukkan bahwa secara umum motivasi belajar fisika siswa kelas XI IPA SMA Negeri 1 Galing tergolong tinggi. Motivasi belajar fisika adalah suatu daya pendorong atau perangsang yang menggerakkan agar siswa melakukan sesuatu yang dalam hal ini perbuatan belajar khususnya dalam mempelajari fisika. Motivasi belajar harus dapat terus ditingkatkan karena siswa yang memiliki motivasi belajar yang tinggi akan memudahkannya dalam belajar sehingga berdampak pada prestasi belajar yang lebih baik. Hal ini sejalan dengan pendapat Djamarah (2011) yang mengatakan bahwa motivasi dalam belajar dapat menentukan baik tidaknya dalam mencapai tujuan, sehingga semakin besar motivasi maka semakin besar kesuksesan dalam belajar, dan berdampak pada meningkatnya prestasi belajar siswa. Jadi, dari ungkapan tersebut dapat dipahami bahwa prestasi belajar yang menjadi tujuan dari proses belajar mengajar didalam kelas akan 
diperoleh maksimal apabila siswa memiliki motivasi yang tinggi.

Menurut Maslow (dalam Djamarah, 2011) mengatakan bahwa tingkah laku manusia dibangkitkan dan diarahkan oleh kebutuhan-kebutuhan tertentu dan kebutuhankebutuhan inilah yang mampu memotivasi tingkah laku. Kebutuhan-kebutuhan tersebut antara lain kebutuhan fisiologis, rasa aman, rasa cinta, penghargaan, aktualisasi diri, mengetahui dan mengerti, dan kebutuhan estetik. Hal ini sejalan hasil observasi motivasi belajar di kelas saat proses belajar mengajar berlangsung, dengan hasil yang menyatakan bahwa motivasi belajar siswa tergolong tinggi. Oleh karena itu, untuk bisa meningkatkan motivasi belajar siswa, guru harus lebih memperhatikan kebutuhan-kebutuhan siswa agar motivasi dapat dibangkitkan.

Data nilai prestasi belajar fisika siswa kelas XI IPA SMA Negeri 1 Galing diperoleh dari guru mata pelajaran fisika tempat penelitian dilakukan, yaitu nilai ulangan akhir semester genap tahun ajaran 2013/2014 seperti yang ditunjukkan dalam Tabel 6 .

Tabel 6. Prestasi Belajar Fisika

\begin{tabular}{clc}
\hline No. & \multicolumn{1}{c}{ Deskripsi Data } & Nilai \\
\hline 1 & Nilai Minimum & 50,00 \\
\hline 2 & Nilai Maksimum & 90,00 \\
\hline 3 & Nilai Rata-rata & 68,47 \\
\hline 4 & Standar Deviasi & 12,20 \\
\hline 5 & Ketuntasan & 48,28 \\
\hline
\end{tabular}

Berdasarkan Tabel 6, diketahui ratarata prestasi belajar belajar pada mata pelajaran fisika siswa kelas XI IPA SMA Negeri 1 Galing Kabupaten Sambas semester genap tahun ajaran 2013/2014 sebesar 68,47, dengan nilai minimum yang adalah 50,00 , sedangkan untuk nilai maksimum adalah 90,00 dengan dan standar deviasi 12,20 serta ketuntasan siswa sebesar $48,28 \%$.

Prestasi belajar fisika adalah hasil pengukuran dari penilaian suatu kegiatan pembelajaran fisika yang dinyatakan dalam bentuk angka yang menunjukkan hasil yang sudah dicapai oleh setiap siswa pada periode tertentu yaitu khususnya penilaian dalam kawasan aspek kognitif.

Hasil penelitian menunjukkan bahwa minat dan motivasi belajar berpengaruh terhadap prestasi belajar fisika. Hal ini dapat dilihat dari persamaan regresi linier berganda sebagai berikut $\mathrm{Y}=-33,04+1,79 \mathrm{X}_{1}+0,52 \mathrm{X}_{2}$. Berdasarkan persamaan tersebut terlihat bahwa koefisien regresi dari minat belajar sebesar 1,79 dan motivasi belajar sebesar 0,52 yang sama-sama bernilai positif, artinya variabel minat belajar dan variabel motivasi belajar secara bersama-sama berpengaruh positif terhadap prestasi belajar fisika siswa.

Berdasarkan hasil uji hipotesis regresi linier berganda diketahui bahwa nilai $\mathrm{F}_{\text {hitung }}=$ $11,00>\mathrm{F}_{\text {tabel }}=3,37$. Hal ini berarti minat dan motivasi belajar secara bersama-sama secara signifikan berpengaruh terhadap prestasi belajar fisika siswa. Artinya dapat dikatakan bahwa kecenderungan peningkatan kombinasi minat dan motivasi belajar akan diikuti peningkatan prestasi belajar fisika siswa, sebaliknya kecenderungan penurunan kombinasi minat dan motivasi belajar akan diikuti penurunan prestasi belajar fisika siswa. Oleh karena itu, peningkatan minat dan motivasi belajar sangat penting untuk dilakukan agar bisa meningkatkan prestasi belajar fisika siswa.

Sejalan dengan penelitian Siagian (2012) menunjukkan bahwa minat belajar mempengaruhi prestasi belajar matematika siswa di SMK PGRI 16 Cipayung Jakarta Timur, dengan hasil penelitian sebesar $\mathrm{t}_{\text {hitung }}=$ $5,489>\mathrm{t}_{\text {Tabel }}=2,048$ yang artinya bahwa terdapat pengaruh antara prestasi belajar terhadap minat belajar siswa. Begitu pula dengan penelitian yang dilakukan Arini (2011) menunjukkan bahwa motivasi belajar berpengaruh sangat signifikan terhadap prestasi akademik siswa kelas II SMA Negeri 99 Jakarta, dengan hasil penelitian diperoleh nilai $t_{\text {hitung }}$ sebesar 3,703 dengan tingkat signifikansi terhadap prestasi akademik.

Hasil analisis menunjukkan bahwa minat dan motivasi keduanya secara signifikan berpengaruh terhadap prestasi belajar fisika. Namun kenyataannya prestasi belajar fisika siswa kelas XI IPA SMA Negeri 1 Galing belum mencapai ketuntasan secara klasikal yaitu $75 \%$, walaupun minat dan motivasi belajar siswa tergolong tinggi. Hal ini disebabkan karena yang mempengaruhi 
prestasi belajar siswa tidak hanya dipengaruhi oleh faktor minat dan motivasi belajar saja tetapi juga dipengaruhi oleh faktor lainnya, dengan koefisien determinasi antara minat dan motivasi belajar terhadap prestasi belajar fisika yang diperoleh sebesar 0,46 , yang artinya $46 \%$ prestasi belajar fisika siswa dipengaruhi oleh minat dan motivasi belajar, sedangkan sisanya sebesar 54\% dipengaruhi oleh faktor lainnya yang tidak termasuk dalam penelitian ini. Menurut Arini (2011), salah satu faktor yang berpengaruh yaitu intelegensi. Begitu pula penelitian yang dilakukan oleh Siagian (2012) yang menyatakan bahwa terdapat pengaruh antara kebiasaan belajar dengan prestasi belajar matematika siswa di SMK PGRI 16 Cipayung Jakarta Timur. Oleh karena itu, untuk meningkatkan prestasi belajar siswa guru untuk lebih memperhatikan faktor-faktor yang mempengaruhi prestasi belajar, terutama berdasarkan hasil penelitian ini guru harus lebih memperhatikan minat dan motivasi belajar siswa, karena minat dan motivasi belajar berpengaruh signifikan terhadap prestasi belajar fisika.

\section{SIMPULAN}

Berdasarkan hasil analisis data dan pembahasan, dapat disimpulkan bahwa terdapat pengaruh minat dan motivasi belajar terhadap prestasi belajar fisika siswa pada siswa kelas XI IPA SMA Negeri 1 Galing Kabupaten Sambas dengan kesimpulan sub masalah antara lain:

a. Minat belajar pada mata pelajaran fisika siswa kelas XI IPA SMA Negeri 1 Galing tergolong tinggi.

b. Motivasi belajar pada mata pelajaran fisika siswa kelas XI IPA SMA Negeri 1 Galing tergolong tinggi.

c. Rata-rata prestasi belajar pada mata pelajaran fisika siswa kelas XI IPA SMA Negeri 1 Galing Kabupaten Sambas semester genap tahun ajaran 2013/2014 sebesar $68,47 \%$.

d. Terdapat pengaruh minat dan motivasi belajar terhadap prestasi belajar fisika pada siswa kelas XI IPA SMA Negeri 1 Galing Kabupaten Sambas

\section{DAFTAR PUSTAKA}

Ahmadi, A. dan Prasetyo. (2005). Strategi Belajar Mengajar. Bandung: Pustaka Setia.

Ali, M. (2011). Pengaruh Kemampuan Profesional Guru terhadap Motivasi Belajar Siswa pada Mata Pelajaran Pkn Siswa Kelas XI SMA Negeri 8 Pontianak. Skripsi. Pontianak: STKIP -PGRI Pontianak. (Skripsi tidak diterbitkan)

Arini, N.K.S. (2011). Pengaruh Tingkat Intelegensi dan Motivasi Belajar terhadap Prestasi Akademik Siswa Kelas II SMA Negeri 99 Jakarta [Online]. Tersedia: www.gunadarma.ac.id/library/articles/.../Ar tikel_10504121.pdf [30 Januari 2014]

Depdiknas. (2003). Undang-undang RI Nomor 20 Tahun 2003 Tentang Sistem Pendidikan Nasional. Bandung: Citra Umbara.

Djamarah, S. B. (2011). Psikologi Belajar Edisi Revisi. Jakarta: Rineka Cipta.

Hamdani. (2011). Strategi Belajar Mengajar. Bandung: Pustaka Setia.

Kanginan, M. (2002). Fisika 1 untuk SMA Kelas X. Jakarta: Erlangga.

Purwanto, N. (2013). Psikologi Pendidikan. Bandung: Remaja Rosdakarya.

Siagian, R.E.F. (2012). Pengaruh Minat dan Kebiasaan Belajar Siswa terhadap Prestasi Belajar Matematika. [Online]. Tersedia: lppmunindra.blogspot.com/.../p-engaruh-minatdan-k-ebiasaan-belajar.html [30 Januari 2014]

Slameto. (2013). Belajar dan Faktor-Faktor yang Mempengaruhinya Edisi Revisi. Jakarta: Rineka Cipta

Sugiyono. (2011). Metodologi Penelitian Kuantitatif, Kualitatif, dan $R \& D$. Bandung: Alfabeta

Syah, M. (2011). Psikologi Pendidikan dengan Pendekatan Baru. Jakarta: Remaja Rosdakarya. 